\title{
Cefepime-induced encephalopathy in patient without renal failure
}

\author{
Encefalopatia induzida por cefepime em paciente sem insuficiência renal \\ Fernando Morgadinho Santos Coelho ${ }^{1}$, Maurício Bernstein², Paula Kiyomi Onaga Yokota ${ }^{3}$, \\ Rosilene Motta Elias Coelho ${ }^{4}$, Marcelo Wachemberg ${ }^{5}$, Letícia Pereira de Brito Sampaio ${ }^{6}$, Luis Otávio Caboclo
}

\begin{abstract}
This case report describes neurotoxicity in an older patient on cefepime $2 \mathrm{~g}$ twice a day. The 81-year-old male patient developed non-convulsive status epilepticus during cefepime treatment with 1 $\mathrm{g}$ twice a day. There was recovery 30 days after discontinuation of cefepime.
\end{abstract}

Keywords: Cephalosporins/adverse effects; Cephalosporins/toxicity; Status epileticus/Chemically induced; Aged; Case reports

\section{RESUMO}

Este relato descreve neurotoxicidade em um paciente mais idoso em uso de cefepime na dose de $2 \mathrm{~g}$ duas vezes ao dia. 0 paciente de 81 anos desenvolveu estado epiléptico não-convulsivo durante 0 tratamento com $1 \mathrm{~g}$ de cefepime duas vezes ao dia. 0 paciente se recuperou depois de 30 dias, após a interrupção do cefepime.

Descritores: Cefalosporinas/efeitos adversos; Cefalosporinas/ toxicidade; Estado epiléptico/induzido quimicamente; Idoso; Relatos de casos

\section{INTRODUCTION}

The existence of acute confusional states associated with the use of cephalosporins in patients with variable degrees of renal failure has been well described. Cephalosporins, particularly cefepime, have been associated with status epilepticus $(\mathrm{SE})^{(1-4)}$. Previous reports focused only patients with no dose adjustment in renal failure. There are several reports of neurotoxicity due to cephalosporins ${ }^{(1-5)}$, but these involve mostly adults with acute or chronic renal failure or those on dialysis, although there are similar case reports for children as well ${ }^{(6,7)}$. There is a significant effect of renal impairment of the elimination half-life and clearance of cefepime. A dose of $1 \mathrm{~g}$ every 24 hours is recommended for patients with glomerular filtration rate (GFR) lower than $10 \mathrm{ml}$ $\min ^{(8)}$. In a study with young male mice (maximum age between six and eight weeks), doses up to $1000 \mathrm{mg} / \mathrm{kg}$ (i.v.), did not induce convulsions in normal conscious mice and rats; however, it produced convulsions in experimental animals with extensive renal failure ${ }^{(9)}$. In elderly patients, renal function decreases and it is important to adjust the cefepime dose when creatinine clearance is lower than $50 \mathrm{ml} \backslash \mathrm{min}^{(10)}$.

\section{CASE REPORT}

An 81-year-old Caucasian diabetic man was admitted for spinal surgery and developed pneumonia. Cefepime $2 \mathrm{~g} /$ day was added to his antibiotic regimen to broaden Pseudomonas aeruginosa coverage. The patient started on intravenous ceftriaxone and clarithromycin for ten days before being given cefepime at $1 \mathrm{~g}$ twice a day instead. After six days of cefepime, he became confused. The neurological examination showed no focal deficits. Computed tomography (CT) of the brain was normal. Cerebrospinal fluid (CSF) examination was negative, and liver function was normal. His renal function deteriorated over 24 hours, 5 days before he displayed neurological symptoms (Table 1). Two days after the onset of mental status changes, an electroencephalography

\footnotetext{
Study carried out at Internal Medicine (Neurology) of Hospital Israelita Albert Einstein - HIAE, São Paulo (SP), Brazil.

${ }^{1}$ Post-doctorate degree at University of Toronto, Canada; MD, Neurologist at Hospital Israelita Albert Einstein - HIAE, São Paulo (SP), Brazil.

2 PhD; Cardiologist at Hospital Israelita Albert Einstein - HIAE, São Paulo (SP), Brazil.

${ }^{3}$ Nursing student at Nursing School of Hospital Israelita Albert Einstein - HIAE, São Paulo (SP), Brazil.

${ }^{4}$ PhD; MD, Nephrologist at Hospital das Clínicas da Faculdade de Medicina da Universidade de São Paulo - USP, São Paulo (SP), Brazil.

${ }^{5}$ MD, Orthopedist at Hospital Israelita Albert Einstein - HIAE, São Paulo (SP), Brazil

${ }^{6} \mathrm{MD}$, Neurologist at Hospital Israelita Albert Einstein - HIAE, São Paulo (SP), Brazil.

7 PhD; Neurologist at Hospital Israelita Albert Einstein - HIAE, São Paulo (SP), Brazil.

Corresponding author: Fernando Morgadinho Santos Coelho - Hospital Israelita Albert Einstein - Avenida Albert Einstein, $627 / 701$ - Morumbi - CEP 05651 -901 - São Paulo (SP), Brazil - Tel.: 11 2272-

4079 - e-mail: fernandomorgadinho@hotmail.com

Received on Nov 26, 2009 - Accepted on Apr 22, 2010
} 
(EEG) revealed diffuse slow-wave activity (delta) and triphasic sharp-wave activity (Figure 1). Cefepime was discontinued, and four days later he was less confused and the new EEG (Figure 2) revealed only diffuse delta. Within 30 days after discontinuation of cefepime, the patient showed recovery in mental status and was able to respond appropriately to questions.

Table 1. Creatinine evolution during cefepime treatment

\begin{tabular}{lcccccccccccccc}
\hline Day & $\mathbf{- 1 0}$ & $\mathbf{- 7}$ & $\mathbf{- 5}$ & $\mathbf{- 4}$ & $\mathbf{- 3}$ & $\mathbf{1}$ & $\mathbf{3}$ & $\mathbf{4}$ & $\mathbf{5}$ & $\mathbf{6}$ & $\mathbf{7}$ & $\mathbf{9}$ & $\mathbf{1 1}$ & $\mathbf{1 7}$ \\
\hline Creatinine $(\mathrm{mg} / \mathrm{gl})$ & 1.1 & 1.1 & 1.3 & 1.4 & 1.2 & 1.0 & 1.9 & 1.3 & 1.1 & 1.0 & 1.0 & 1.1 & 1.0 & 1.0 \\
Blood urea nitrogen $(\mathrm{mg})$ & 15 & 11 & 17 & 34 & 37 & 20 & 44 & 48 & 39 & 39 & 39 & 47 & 39 & 21
\end{tabular}

Cefepime was started in the day 1 and symptoms began in the day 10 .

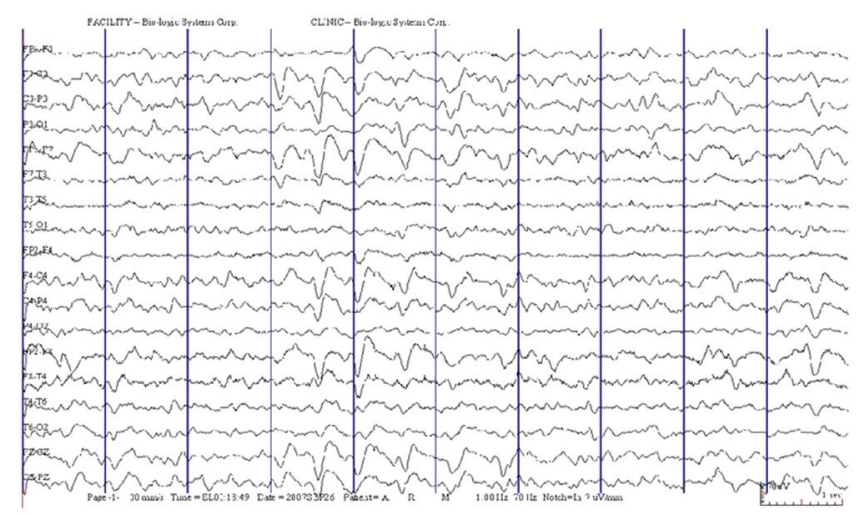

Figure 1. First electroencephalogram showing generalized sharp and slow wave discharges

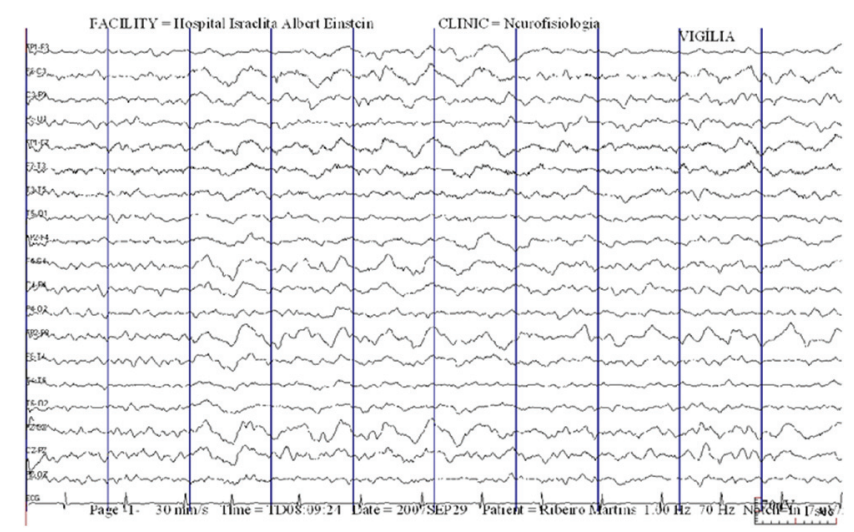

Figure 2. Second electroencephalogram showing generalized delta activities, after cefepime was discontinued

\section{DISCUSSION}

Beta-lactam antibiotics produce convulsions via their gamma-aminobutyric acid (GABA) antagonist properties and by enhancing glutamate-mediated excitatory neurotransmission ${ }^{(9)}$. Convulsive activities of different $\beta$-lactam antibiotics were investigated using intracerebroventricular (ICV) administration in mice. Cefepime has relatively potent intrinsic convulsive activity ${ }^{(11)}$. Some studies demonstrated that these antibiotics competitively inhibit GABA-induced chloride currents by binding directly to the receptor, thus resulting in an inhibition of an inhibitory response leading to depolarization of the postsynaptic membrane potential $^{(12-14)}$.

Elderly patients present with decreased creatinine clearance with age. For example, a 70 -year-old, $70 \mathrm{~kg}$ patient with $1 \mathrm{mg} / \mathrm{dl}$ creatinine has a clearance of 45 $\mathrm{ml} \backslash \mathrm{min}$. The glomerular filtration rate (GFR) must decline to about half of the normal level before the serum creatinine concentration rises above the upper limit of normal. Monitoring of renal function is needed in older patients with severe disease, sepsis, and those who are receiving nephrotoxic therapy. Specifically in our patient, a serum creatinine of $1.2 \mathrm{mg} / \mathrm{dl}$ corresponds to a clearance of $50 \mathrm{ml} / \mathrm{min}$ (Figure 3 ), and requires a dose adjustment of the antibiotic. In elderly patients and normal subjects in medical or surgical wards, the renal function should be checked to allow daily adjustments of the cefepime dose.

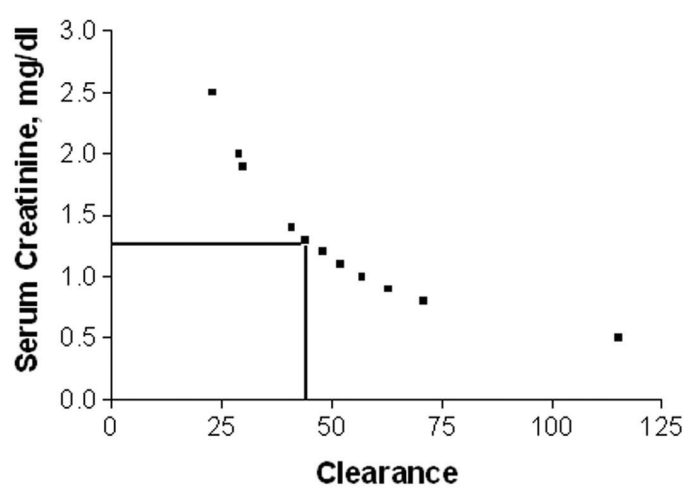

Figure 3. Relationship between creatinine and clearance (by Cockroft-Gault formula)

\section{REFERENCES}

1. Martinez-Rodriguez JE, Barriga FJ, Santamaria J, Iranzo A, Pareja JÁ, Revilla $M$, et al. Nonconvulsive status epilepticus associated with cephalosporins in patients with renal failure. Am J Med. 2001;111(2):115-9.

2. Primavera A, Cocito L, Audenino D. Nonconvulsive status epilepticus during cephalosporin therapy. Neuropsychobiology. 2004;49(4):218-22.

3. Dixit S, Kurle P, Buyan-Dent L, Sheth RD. Status epilepticus associated with cefepime. Neurology. 2000;54(11):2153-5.

4. Abanades S, Nolla J, Rodriguez-Campello A, Pedro C, Valls A, Farre M. Reversible coma secondary to cefepime neurotoxicity. Ann Pharmacother. 2004;38(4):606-8.

5. Plensa E, Gallardo E, Ribera JM, Oriol A, Costa J. Nonconvulsive status epilepticus associated with cefepime in a patient undergoing autologous stem cell transplantation. Bone Marrow Transplant. 2004;33(1):119-20.

6. Alpay H, Altun 0, Biyikli NK. Cefepime-induced non-convulsive status epilepticus in a peritoneal dialysis patient. Pediatr Nephrol. 2004;19(4):445-7.

7. Chedrawi AK, Gharaybeh SI, Al-Ghwery SA, Al-Mohaimeed SA, Alshahwan SA. Cephalosporin-induced nonconvulsive status epilepticus in a uremic child. Pediatr Neurol. 2004;30(2):135-9. 
8. Rybak M. The pharmacokinetic of profile of a new generation of parental cephalosporin. Am J Med. 1996;100(Supl 6A):39-44.

9. Sugimoto M, Uchida I, Mashimo T, Yamazaki S, Hatano K, Ikeda F, et al. Evidence for the involvement of GABA (A) receptor blockade in convulsions induced by cephalosporins. Neuropharmacology. 2003;45(3):304-14.

10. Maganti R, Jolin D, Rishi D, Biswas A. Nonconvulsive status epilepticus due to cefepime in a patient with normal renal function. Epilepsy Behav. 2006;8(1):312-4.

11. Mine $Y$, Watanabe $Y$, Sakamoto $H$, Hatano K, Kuno K, Kamimura T, et al. In vitro antibacterial activity of FK037, a novel parenteral broad-spectrum cephalosporin against methicillin-resistant staphylococci. J Antibiot (Tokyo). 1993;46(1):99-119.
12. Akaike N, Hattori K, Oomura Y, Carpenter DO. Bicuculline and picrotoxin block gamma-aminobutyric acid-gated $\mathrm{Cl}$ - conductance by different mechanisms. Experientia. 1985;41(1):70-1.

13. Barker JL, McBurney RN, Mathers DA. Convulsant-induced depression of amino acid responses in cultured mouse spinal neurons studied under voltage clamp. Br J Pharmacol. 1983;80(4):619-29.

14. Bormann J, Clapham DE. gamma-Aminobutyric acid receptor channels in adrenal chromaffin cells: a patch-clamp study. Proc Natl Acad Sci U S A. 1985;82(7):2168-72. 